\title{
ANALISA KUALITAS WEB EMPLOYEE SELF SERVICE (ESS) PADA PT. PLN UIPJBB MENGGUNAKAN METODE WEBQUAL 4.0 DAN IPA
}

\author{
Heru Susanto'), Suparni' ${ }^{2}$, Lilyani Asri Utami ${ }^{3)}$ \\ 1,3Program Studi Sistem Informasi, STMIK Nusa Mandiri, Jl. Jatiwaringin Raya No. 02, \\ Cipinang Melayu, Makassar, Jakarta Timur \\ email: scooter.race77@gmail.com, lilyani.lau@nusamandiri.ac.id \\ ${ }^{2}$ Program Studi Teknologi Informasi, Fakultas Teknik dan Informatika, Universitas Bina \\ Sarana Informatika, Jl. Kramat Raya No. 98, Senen, Jakarta Pusat \\ email: suparni.spn@,bsi.ac.id
}

\begin{abstract}
PT PLN (Persero) West Java Development Main Unit (UIPJBB) has used an information system to make it easier for employees to access information and personnel activities such as attendance, leave, $C V$, information on the stages of requesting an Official Travel Letter (SPPD), and other related information. with staffing by using a web called Employee Self Service (ESS). The quality of ESS web services has never been measured based on user perceptions and levels of importance or expectations. This study intends to analyze the quality of the ESS web using WebQual 4.0 as a questionnaire consisting of three dimensions in the form of Usability, Information Quality, and Service Interaction dimensions, as well as using the IPA method to analyze the level of conformity, compliance (GAP), and quadrants. The results of the level of conformity obtained from 22 statements were still below 100\%. The test result statistic shows Asymp.Sig. (2-tailed) worth 0,000 means that there is a gap between Importance and Performance on the ESS website of PT PLN (Persero) UIPJBB. The average of the overall level of conformity is obtained 93.53\%, which means that the performance on the web ESS is still below Importance and users are still not satisfied. While the results of GAP analysis are $-0.262<0$, then the quality of performance is still lacking and cannot meet the interests of users.
\end{abstract}

Keywords: Webqual, Importance Performance Analysis, web, ESS, PLN.

\begin{abstract}
Abstrak
PT PLN (Persero) Unit Induk Pembangunan Jawa Bagian Barat (UIPJBB) telah menggunakan suatu sistem informasi untuk memudahkan pegawai dalam mengakses informasi dan kegiatan kepegawaian seperti absensi, cuti, CV, informasi tahapan permohonan Surat Perjalanan Dinas (SPPD), dan informasi lainnya yang berhubungan dengan kepegawaian yaitu dengan menggunakan web bernama Employee Self Service (ESS). Kualitas layanan web ESS belum pernah diukur berdasarkan persepsi dan tingkat kepentingan atau harapan pengguna. Penelitian ini bermaksud untuk menganalisa kualitas web ESS menggunakan WebQual 4.0 sebagai kuesioner yang terdiri atas tiga dimensi yang berupa dimensi Usability, Information Quality, dan Service Interaction, serta menggunakan metode IPA untuk menganalisis tingkat kesesuaian, kepatuhan (GAP), dan kuadran. Hasil tingkat kesesuaian yang didapatkan dari 22 pernyataan masih dibawah 100\%. Statistik Hasil Uji menunjukkan Asymp.Sig. (2-tailed) bernilai 0,000 artinya ada kesenjangan antara Importance
\end{abstract}


dengan Performance pada web ESS PT PLN (Persero) UIPJBB. Rata-rata dari keseluruhan tingkat kesesuaian diperoleh 93,53\% yang berarti bahwa Performance pada web ESS masih di bawah Importance dan pengguna masih merasa tidak puas. Sedangkan hasil Analisa GAP sebesar -0,262 $<0$ maka kualitas kinerja masih kurang dan belum bisa memenuhi kepentingan pengguna.

Kata Kunci: Webqual, Importance Performance Analysis, web, ESS, PLN.

\section{PENDAHULUAN}

PT PLN (Persero) Unit Induk Pembangunan Jawa Bagian Barat (UIPJBB) dalam penyampaian informasi dan kegiatan yang berhubungan dengan kepegawaian telah mengunaan aplikasi berbasis web yaitu Employee Self Service (ESS) untuk memudahkan pegawai dalam mengakses informasi kepegawaian dan kegiatan-kegiatan kepegawaian seperti absensi, cuti, data pribadi, informasi penghasilan, permohonan Surat Perintah Perjalanan Dinas (SPPD), dan informasi lainnya yang berhubungan dengan kepegawaian. Namun informasi yang diberikan terkadang terlambat dan beberapa fungsi dari menu yang terdapat pada web ESS tersebut belum dapat digunakan dikarenakan menggunakan aplikasi yang berbeda sehingga menyulitkan pengguna dalam memperoleh informasi dan penggunaan web ESS tersebut. Sejak awal penggunaan web ESS pada Oktober 2015 di PT PLN (Persero) UIPJBB belum pernah dilakukan pengukuran kualitas berdasarkan persepsi dan kepentingan atau harapan pengguna.

Website memiliki peran dan fungsi yang sangat penting sehingga dalam perancangannya harus memperhatikan beberapa faktor yang dapat mempengaruhinya yaitu usability, user experience dan user interface [1]. Layanan suatu website perlu diukur untuk mengetahui pengaruh kualitas layanan terhadap kepuasan pelanggan. Untuk mengukur kualitas website berdasarkan persepsi pengguna akhir maka digunakan metode WebQual 4.0. Keunggulan metode WebQual yaitu melakukan teknik pengukuran berdasarkan persepsi pengguna akhir [2]. Adapun instrumen-instrumen penelitian yang digunakan dalam WebQual 4.0 yaitu Usability Quality, Information Quality, dan Interaction Quality dan hasilnya akan dianalisis dengan metode Importance Performance Analysis (IPA). IPA adalah metode untuk mengukur kepuasan pengguna terhadap sebuah barang atau jasa yang ditawarkan. Pendekatan IPA didasari oleh kepentingan atau harapan (importance) dan kinerja (performance) pada produk atau jasa yang ada [3].

Penggunaan metode WebQual dan IPA telah banyak digunakan oleh para peneliti diantaranya dalam bidang pengelolaan pemerintahan yang baik (good governance) dilakukan pengukuran kualitas situs web Kecamatan Lowokwaru sebagai acuan masyarakat dalam mendapatkan berbagai infomasi [4]. Penelitian untuk mengetahui tingkat kualitas website Viu.com yang dinilai dari kualitas aktual yang dirasakan dan tingkat ideal yang diinginkan pengguna Viu membuktikan adanya atribut atau indikator yang menjadi fokus perbaikan perusahaan yaitu tampilan website, keamanan data pribadi pengguna, dan service yang diterima sesuai [5]. Penelitian untuk mengetahui tingkat kualitas Ruangguru.com berdasarkan penilaian pengguna terhadap kualitas aktual yang dirasakan dan kualitas ideal yang diharapkan menunjukkan kualitas actual yang dirasakan belum bisa memenuhi kualitas ideal yang diinginkan pengguna website Ruangguru.com terutama dari atribut kualitas yang berhubungan dengan service interaction dalam website [6]. Berdasarkan permasalahan yang telah diuraikan dan penelitian terkait, maka peneliti akan melakukan penelitian tentang pengukuran kualitas web Employee Self Service (ESS) pada PT. PLN (Persero) Unit Induk Pembangunan Jawa Bagian Barat (UIPJBB) menggunakan metode WebQual 4.0 dan IPA berdasarkan persepsi pengguna terakhir yang didasari oleh kepentingan dan kinerja web tersebut. 


\section{TINJAUAN PUSTAKA}

\subsection{Website}

Website adalah kumpulan halaman-halaman web yang mengandung informasi yang disediakan melalui jalur internet, sehingga bisa diakses di seluruh dunia selama terhubung dengan jaringan internet [7]. Website mempunyai fungsi sebagai berikut [5]

1. Fungsi Komunikasi

Website yang mempunyai fungsi komunikasi pada umumnya adalah situs website dinamis. Karena dibuat menggunakan pemrograman web maka dilengkapi fasilitas yang diberikan fungsi-fungsi komunikasi, seperti website main, form contact, chatting, forum dan lainnya.

2. Fungsi Informasi

Situs website memiliki fungsi informasi pada umumnya lebih menekankan pada kualitas kontenya karena tujuan situs tersebut adalah menyampaikan isinya. Situs ini sebaiknya berisi dan grafik yang dapat diunduh dengan cepat. Pembatasan pengguna animasi gambar dan elemen-elemen bergerak seperti shockwave dan java diyakini sebagai langkah yang tepat diganti dengan fasilitas yang memberikan fungsi informasi seperti news, profile company, library, reference dan lain- lain.

3. Fungsi Entertainment

Situs web juga dapat memiliki fungsi entertainment. Bila situs web berfungsi sebagai hiburan maka pengguna animasi gambar dan elemen bergerak dapat meningkatkan mutu presentasi desainnya, meski harus tetap memperhatikan kecepatan download. Beberapa fasilitas yang memberikan fungsi hiburan adalah game online, film, online music, dan sebagainnya.

4. Fungsi Transaksi

Situs website dijadikan sarana transaksi bisnis, baik barang, jasa, atau lainnya. Situs web ini menghubungkan perusahaan, konsumen, dan komunitas tertentu melalui transaksi elektronik hingga metode pembayaran bisa menggunakan kartu kredit, transfer, atau dengan membayar secara langsung dapat dilakukan dengan mudah dan cepat.

\subsection{WebQual 4.0}

Webqual merupakan salah satu metode atau teknik pengukuran kualitas website berdasarkan persepsi pengguna akhir. Metode Webqual 4.0 tersebut disusun berdasarkan penelitian pada tiga instrumen yaitu Information Quality, Service Interaction Quality, dan Usability [8].

1. Usability Quality

Kualitas informasi meliputi hal - hal seperti informasi yang akurat, informasi yang bisa di percaya, informasi yang up to date atau terbaru, informasi yang sesuai dengan topik bahasan, informasi yang mudah dimengerti, informasi yang sangat detail dan mendalam, dan informasi yang disajikan dalam format desain yang sesuai [8]. Berikut ini tiga komponen umum usability:

a. Adanya keterlibatan seorang pengguna.

b. Pengguna melakukan suatu pekerjaan.

c. Pengguna melakukan sesuatu dengan adanya produk, sistem atau hal.

2. Information Quality 
Kulitas informasi dari penelitian sistem informasi (Information Quality) adalah mutu dari isi yang terdapat pada site, pantas tidaknya informasi untuk tujuan pengguna seperti akurasi, format dan keterkaitannya.

3. Service Interaction Quality

Service Interaction Quality adalah mutu dari interaksi pelayanan yang dialami oleh pengguna ketika mereka menyelidiki kedalam site lebih dalam, yang terwujud dengan kepercayaan dan empati, sebagai contoh isu dari keamanan transaksi dan informasi, pengantaran produk, personalisasi dan komunikasi dengan pemilik site. Adapun dimensi dan item webqual [9] dapat dilihat pada Tabel 1.

\section{Tabel 1. Indikator WebQual 4.0}

\begin{tabular}{ll}
\hline \multicolumn{1}{c}{ Variabel } & \multicolumn{1}{c}{ Webqual 4.0 Item } \\
\hline Kualitas Pengguna & 1. Kemudahan untuk dioperasikan. \\
& 2. Interaksi dengan website jelas dan dapat dimengerti. \\
& 3. Kemudahan untuk navigasi. \\
& 4. Kemudahan menemukan alamat website. \\
& 5. Tampilan yang atraktif. \\
& 6. Tepat dalam penyusunan tata letak informasi. \\
& 7. Tampilan sesuai dengan jenis website company \\
& profile. \\
8. Adanya penambahan pengetahuan dari informasi \\
website.
\end{tabular}

Sumber: [9]

\subsection{Importance Performance Analysis (IPA)}

Importance Performance Analysis (IPA) adalah metode untuk mengukur kepuasan pengguna terhadap sebuah barang atau jasa yang ditawarkan. Pendekatan IPA didasari oleh kepentingan atau harapan (importance) dan kinerja (performance) pada produk atau jasa yang ada. IPA mempunyai fungsi untuk menampilkan informasi dalam bentuk diagram kartesius yang berkaitan indikator-indikator kualitas yang menurut pengguna dapat mempengaruhi loyalitas dan kepuasaan. Untuk menentukan nilai kesenjangan, maka dapat dilihat dari selisih antara nilai kualitas aktual (performance) dan kualitas ideal (importance) 
[5]. Hasil matriks importance performance yang dipetakan kedalam empat kuadran sebagaimana ditunjukan dalam Gambar 1.

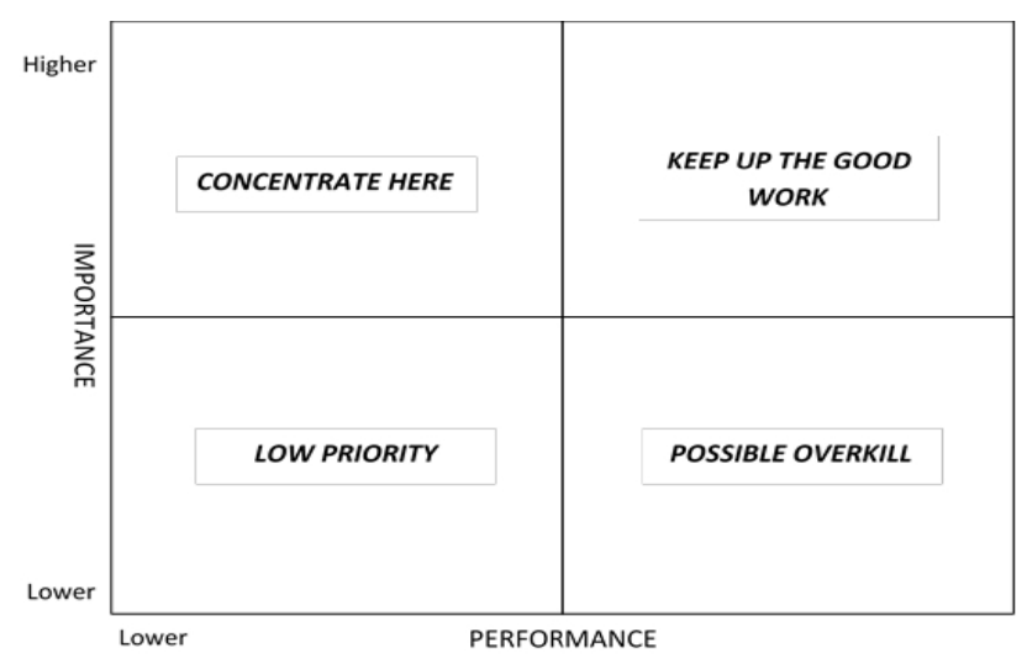

Sumber: [5]

\section{Gambar 1. IPA Framework}

Berikut penjelasan untuk masing-masing kuadran [10].

1. Kuadran pertama: Pertahankan Kinerja (high importance dan high perfomance). Dianggap sebagai faktor penunjang bagi kepuasan konsumen sehingga manajemen wajib memastikan kinerja institusinya dapat mempertahankan prestasi yang telah dicapai.

2. Kuadran kedua: Cenderung Berlebihan (low importance dan high performance). Dianggap tidak terlalu penting sehingga manajemen bisa mengalokasikan sumber daya yang terkait dengan faktor-faktor tersebut kepada faktor-faktor lain yang lebih membutuhkan peningkatan penanganan.

3. Kuadran ketiga: Prioritas rendah (low importance dan low performance). Dianggap mempunyai tingkat kepuasan yang rendah sekaligus dianggap tidak terlalu penting oleh konsumen, sehingga manajemen tidak perlu memprioritaskan faktor tersebut.

4. Kudran keempat: Tingkatkan Kinerja (high importance dan low performance).

Dianggap faktor yang sangat penting namun belum memuaskan untuk kondisi saat ini sehingga harus menjadi perhatian bagi manajemen untuk mengalokasikan sumber daya yang memadai.

\subsection{Skala Likert}

Definisi skala likert adalah skala yang digunakan untuk mengukur persepsi, sikap atau pendapat seseorang atau kelompok mengenai sebuah peristiwa atau fenomena sosial [11]. Terdapat dua jenis model analisa data pada skala likert, yaitu analisi frekuensi (proposi) dan analisis terbanyak (mode). Skala likert menggunakan beberapa butir pertanyaan untuk mengukur perilaku individu dengan merespon lima titik pilihan pada setiap butir pertanyaan, sebagai berikut:

1. Sangat Setuju/Baik/Suka.

2. Setuju/Baik/Suka.

3. Kurang Setuju/Baik/Suka.

4. Tidak Setuju/Baik/Suka.

5. Sangat Tidak Sejutu/Baik/Suka. 


\subsection{Uji Validitas}

Uji Validitas dilakukan untuk memastikan seberapa baik suatu instrumen digunakan untuk mengukur konsep yang seharusnya diukur. Pengujian validitas dilakukan dengan mengkorelasikan anatara skor butir pertanyaan dengan skor totalnya [12].

\subsection{Uji Reabilitas}

Reabilitas menunjuk pada suatu pengertian bahwa suatu instrumen cukup dapat dipercaya untuk dapat digunakan sebagai alat pengumpul data karena instrumen tersebut sudah baik [12]. Reabilitas berkenaan dengan ketepatan hasil pengukuran, instrumen dikatakan reliabel jika dapat memberikan hasil yang relatif sama saat dilakukan pengukuran kembali kepada objek lain pada waktu yang berbeda atau dapat memberikan hasil yang tetap.

\subsection{Populasi}

Populasi adalah wilayah generalasi yang terdiri atas objek/subjek yang memiliki kuantitas dan karakteristik tertentu yang ditetapkan oleh peneliti untuk dipelajari dan kemudian ditarik kesimpulannya [13]. Dalam melakukan penelitian kita harus mempunyai objek dan juga subjek. Sehingga ketika membicarakan objek penelitian, mengharuskan kita juga untuk membicarakan subjek penelitian yang merupakan karakteristik atau sifat yang menjadi perhatian peneliti.

\subsection{Sampel}

Sampel adalah sebagian dari jumlah dan karakteristik yang dimiliki oleh populasi tersebut. Penelitian populasi dilakukan jika jumlah populasi di bawah 100 orang, apabila populasi lebih dari 100 orang maka harus dilakukan pengambilan sampel [13]. Pengambilan sampel dilakukan bila populasi besar dan peneliti tidak memungkinkan mempelajari semua yang ada pada populasi tersebut, untuk itu sampel yang diambil dari populasi harus betul-betul representatif (mewakili) populasi.

\subsection{SPSS}

SPSS adalah program komputer yang digunakan untuk membuat analisis statistika [14]. SPSS dapat membaca jenis data atau masukan data secara langsung ke dalam SPSS Data Editor. Bagaimanapun struktur dari file data mentahnya, maka data dalam Data Editor SPSS harus dibentuk dalam bentuk baris (cases) dan kolom (variables). Case berisi informasi untuk satu unit analisis, sedangkan variable adalah informasi yang dikumpulkan dari masing-masing kasus.

\section{METODE PENELITIAN}

Metode penelitian yang digunakan terdiri dari beberapa tahapan penelitian yang dapat dilihat pada Gambar 2. 


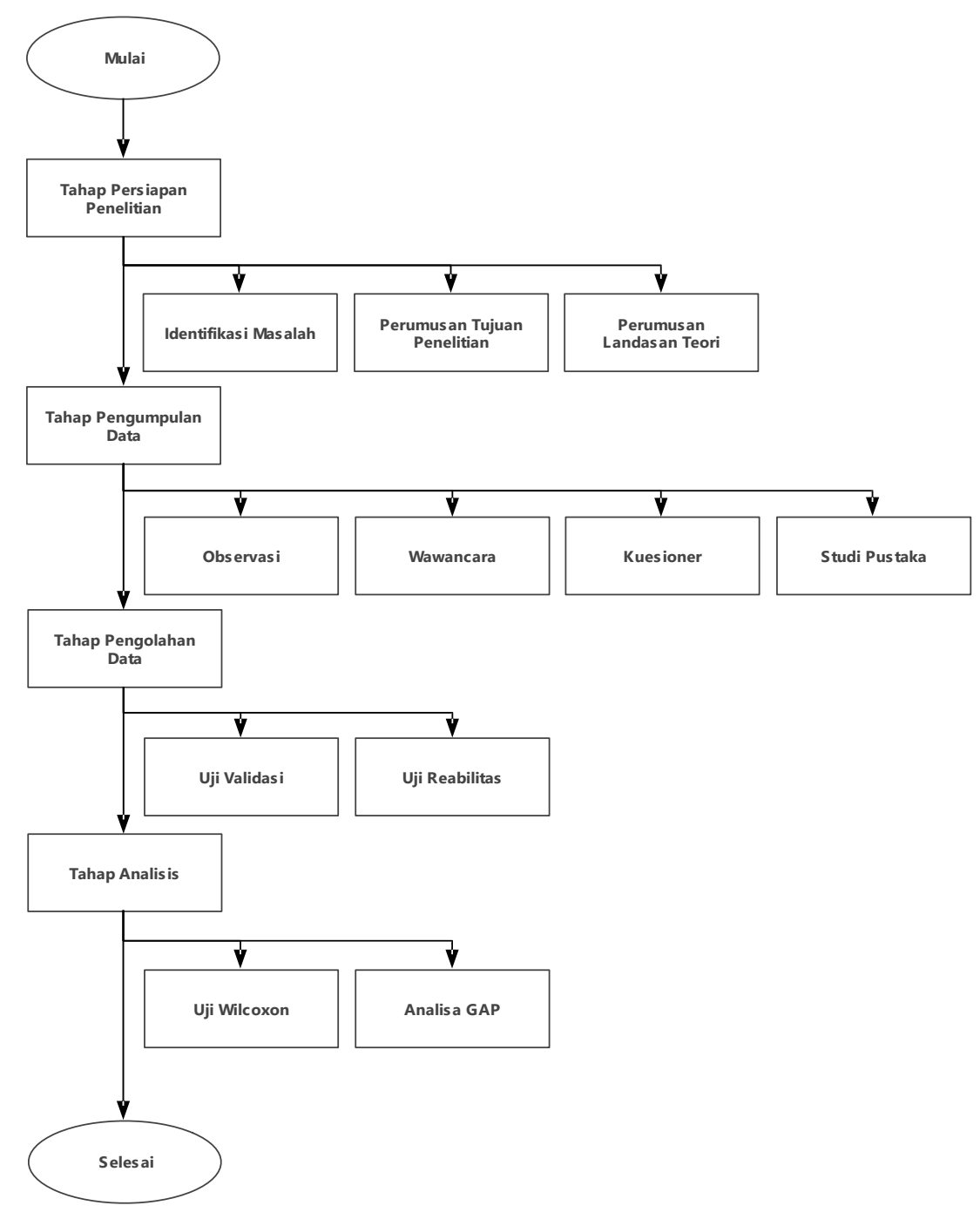

Gambar 2. Tahapan Penelitian

\section{HASIL DAN PEMBAHASAN}

\subsection{Hasil Perhitungan Uji Validitas}

Tabel 2. Hasil Perhitungan Uji Validitas Instrument Usability Quality

\begin{tabular}{|c|c|c|c|c|c|}
\hline \multirow{2}{*}{$\begin{array}{l}\text { No. } \\
\text { I tem }\end{array}$} & \multicolumn{2}{|c|}{$r_{x y}$} & \multirow[b]{2}{*}{$\begin{array}{c}r_{\text {tabel }} \\
5 \%(147-2)\end{array}$} & \multicolumn{2}{|c|}{ Keputusan } \\
\hline & $\begin{array}{c}\text { Performance } \\
\text { (X1) }\end{array}$ & $\begin{array}{c}\text { I mportance } \\
\text { (Y 1) }\end{array}$ & & $\begin{array}{l}\text { Performance } \\
\text { (X1) }\end{array}$ & $\begin{array}{c}\text { Importance } \\
\text { (Y 1) }\end{array}$ \\
\hline 1 & 0,800 & 0,658 & 0,136 & Valid & Valid \\
\hline 2 & 0,820 & 0,774 & 0,136 & Valid & Valid \\
\hline 3 & 0,810 & 0,807 & 0,136 & Valid & Valid \\
\hline 4 & 0,794 & 0,758 & 0,136 & Valid & Valid \\
\hline 5 & 0,664 & 0,678 & 0,136 & Valid & Valid \\
\hline 6 & 0,727 & 0,623 & 0,136 & Valid & Valid \\
\hline 7 & 0,736 & 0,510 & 0,136 & Valid & Valid \\
\hline 8 & 0,707 & 0,550 & 0,136 & Valid & Valid \\
\hline
\end{tabular}


Tabel 3. Hasil Perhitungan Uji Validitas Instrument Information Quality

\begin{tabular}{|c|c|c|c|c|c|}
\hline \multirow{2}{*}{$\begin{array}{l}\text { No. } \\
\text { I tem }\end{array}$} & \multicolumn{2}{|c|}{$r_{x y}$} & \multirow[b]{2}{*}{$\begin{array}{c}r_{\text {tabel }} \\
5 \%(147-2)\end{array}$} & \multicolumn{2}{|c|}{ Keputusan } \\
\hline & $\begin{array}{l}\text { Performance } \\
\text { (X 1) }\end{array}$ & $\begin{array}{c}\text { I mportance } \\
\text { (Y 1) }\end{array}$ & & $\begin{array}{l}\text { Performance } \\
\text { (X1) }\end{array}$ & $\begin{array}{c}\text { I mportance } \\
\text { (Y 1) }\end{array}$ \\
\hline 1 & 0,833 & 0,863 & 0,136 & Valid & Valid \\
\hline 2 & 0,797 & 0,898 & 0,136 & Valid & Valid \\
\hline 3 & 0,866 & 0,795 & 0,136 & Valid & Valid \\
\hline 4 & 0,827 & 0,887 & 0,136 & Valid & Valid \\
\hline 5 & 0,618 & 0,770 & 0,136 & Valid & Valid \\
\hline 6 & 0,687 & 0,834 & 0,136 & Valid & Valid \\
\hline 7 & 0,641 & 0,527 & 0,136 & Valid & Valid \\
\hline
\end{tabular}

Tabel 4. Hasil Perhitungan Uji Validitas Instrument Interaction Quality

\begin{tabular}{|c|c|c|c|c|c|}
\hline \multirow{2}{*}{$\begin{array}{l}\text { No. } \\
\text { Item }\end{array}$} & \multicolumn{2}{|c|}{$\mathbf{r}_{\mathrm{xy}}$} & \multirow{2}{*}{$\begin{array}{c}r_{\text {tabel }} \\
5 \%(147-2)\end{array}$} & \multicolumn{2}{|c|}{ Keputusan } \\
\hline & $\begin{array}{c}\text { Performance } \\
\text { (X1) }\end{array}$ & $\begin{array}{c}\text { Importance } \\
(\text { ( 1) }\end{array}$ & & $\begin{array}{l}\text { Performance } \\
\text { (X 1) }\end{array}$ & $\begin{array}{c}\text { I mportance } \\
\text { (Y 1) }\end{array}$ \\
\hline 1 & 0,749 & 0,668 & 0,136 & Valid & Valid \\
\hline 2 & 0,740 & 0,765 & 0,136 & Valid & Valid \\
\hline 3 & 0,772 & 0,773 & 0,136 & Valid & Valid \\
\hline 4 & 0,669 & 0,649 & 0,136 & Valid & Valid \\
\hline 5 & 0,633 & 0,845 & 0,136 & Valid & Valid \\
\hline 6 & 0,633 & 0,684 & 0,136 & Valid & Valid \\
\hline 7 & 0,760 & 0,707 & 0,136 & Valid & Valid \\
\hline
\end{tabular}

Dapat dilihat dari Tabel 2 bahwa semua pernyataan pada instrument Usability Quality dinyatakan valid, dilihat dari Tabel 3 bahwa pernyataan pada instrument Information Quality dinyatakan valid dan pada Tabel 4 bahwa pernyataan instrument Interaction juga dinyatakan valid.

\subsection{Hasil Perhitungan Uji Reliabilitas}

Perhitungan uji reliabilitas didasarkan pada pedoman dari Tabel 5.

Tabel 5. Kriteria Uji Reliabilitas

\begin{tabular}{|c|l|}
\hline Hasil Perhitungan & \multicolumn{1}{c|}{ Derajat Reabilitas } \\
\hline $0,000-0,199$ & Sangat Rendah \\
\hline $0,200-0,399$ & Rendah \\
\hline $0,400-0,599$ & Sedang \\
\hline $0,600-0,799$ & Tinggi \\
\hline $0,800-1,000$ & Sangat Tinggi \\
\hline
\end{tabular}

Dari hasil perhitungan uji reliabilitas, maka diperoleh hasil reliabilitas dari instrument Usability, Information, dan Interaction Quality yang dapat dilihat pada Tabel 6. 
Tabel 6. Hasil Uji Reliabilitas

\begin{tabular}{|c|l|r|r|r|r|}
\hline \multirow{2}{*}{$\begin{array}{c}\text { No. } \\
\text { I tem }\end{array}$} & \multicolumn{1}{|c|}{ Variabel } & \multicolumn{2}{|c|}{ Koevesien r } & \multicolumn{2}{|c|}{ Reabilitas } \\
\cline { 3 - 6 } & $\begin{array}{c}\text { Performance } \\
(\mathbf{X})\end{array}$ & $\begin{array}{c}\text { Importance } \\
(\mathbf{Y})\end{array}$ & $\begin{array}{c}\text { Performance } \\
(\mathbf{X})\end{array}$ & $\begin{array}{c}\text { Importance } \\
\text { (Y) }\end{array}$ \\
\hline 1 & Usability Quality & 0,884 & 0,881 & Sangat Tinggi & Sangat Tinggi \\
\hline 2 & Information Quality & 0,876 & 0,895 & Sangat Tinggi & Sangat Tinggi \\
\hline 3 & Interaction Quality & 0,825 & 0,852 & Sangat Tinggi & Sangat Tinggi \\
\hline
\end{tabular}

Dilihat dari Tabel 6 yang menyatakan semua variable dalam instrument penelitian memiliki reliabel sangat tinggi, dapat disimpulkan bahwa setiap variabel penelitian konsisten dalam memberikan pernyataan.

\subsection{Importance Performance Analysis (IPA)}

1. Pemberian Bobot Nilai dan Perhitungan Rata-Rata

Tabel 7. Bobot Nilai dan Perhitungan Rata-Rata Nilai Performance (X)

\begin{tabular}{|c|c|c|c|c|c|c|c|c|c|c|c|c|}
\hline \multirow{3}{*}{ Variabel } & \multicolumn{10}{|c|}{ Performance (X) } & \multirow{3}{*}{ Total Skor } & \multirow{3}{*}{$\begin{array}{c}\text { Rata-R ata } \\
\text { (X) }\end{array}$} \\
\hline & \multicolumn{5}{|c|}{ Skala } & \multicolumn{5}{|c|}{ Skor } & & \\
\hline & 1 & 2 & 3 & 4 & 5 & 1 & 2 & 3 & 4 & 5 & & \\
\hline $\mathrm{X} 1.1$ & 0 & 1 & 18 & 115 & 13 & 0 & 2 & 54 & 460 & 65 & 581 & 3,952 \\
\hline $\mathrm{X} 1.2$ & 0 & 2 & 18 & 118 & 9 & 0 & 4 & 54 & 472 & 45 & 575 & 3,912 \\
\hline X1.3 & 1 & 2 & 23 & 116 & 5 & 1 & 4 & 69 & 464 & 25 & 563 & 3,830 \\
\hline $\mathrm{X} 1.4$ & 0 & 2 & 22 & 114 & 9 & 0 & 4 & 66 & 456 & 45 & 571 & 3,884 \\
\hline X1.5 & 1 & 9 & 56 & 79 & 2 & 1 & 18 & 168 & 316 & 10 & 513 & 3,490 \\
\hline X1.6 & 1 & 1 & 33 & 109 & 3 & 1 & 2 & 99 & 436 & 15 & 553 & 3,762 \\
\hline X1.7 & 2 & 12 & 40 & 91 & 2 & 2 & 24 & 120 & 364 & 10 & 520 & 3,537 \\
\hline X1.8 & 1 & 6 & 28 & 108 & 4 & 1 & 12 & 84 & 432 & 20 & 549 & 3,735 \\
\hline X2.1 & 0 & 9 & 25 & 107 & 6 & 0 & 18 & 75 & 428 & 30 & 551 & 3,748 \\
\hline X2.2 & 0 & 8 & 20 & 110 & 9 & 0 & 16 & 60 & 440 & 45 & 561 & 3,816 \\
\hline X2.3 & 1 & 13 & 42 & 89 & 2 & 1 & 26 & 126 & 356 & 10 & 519 & 3,531 \\
\hline X2.4 & 0 & 11 & 21 & 111 & 4 & 0 & 22 & 63 & 444 & 20 & 549 & 3,735 \\
\hline X2.5 & 0 & 2 & 18 & 125 & 2 & 0 & 4 & 54 & 500 & 10 & 568 & 3,864 \\
\hline X2.6 & 0 & 5 & 32 & 108 & 2 & 0 & 10 & 96 & 432 & 10 & 548 & 3,728 \\
\hline X2.7 & 0 & 5 & 20 & 118 & 4 & 0 & 10 & 60 & 472 & 20 & 562 & 3,823 \\
\hline X3.1 & 0 & 10 & 21 & 112 & 4 & 0 & 20 & 63 & 448 & 20 & 551 & 3,748 \\
\hline X3.2 & 0 & 3 & 16 & 122 & 6 & 0 & 6 & 48 & 488 & 30 & 572 & 3,891 \\
\hline X3.3 & 1 & 2 & 14 & 122 & 8 & 1 & 4 & 42 & 488 & 40 & 575 & 3,912 \\
\hline X3.4 & 1 & 0 & 26 & 114 & 6 & 1 & 0 & 78 & 456 & 30 & 565 & 3,844 \\
\hline X3.5 & 0 & 4 & 18 & 115 & 10 & 0 & 8 & 54 & 460 & 50 & 572 & 3,891 \\
\hline X3.6 & 1 & 14 & 32 & 95 & 5 & 1 & 28 & 96 & 380 & 25 & 530 & 3,605 \\
\hline X3.7 & 1 & 0 & 18 & 125 & 3 & 1 & 0 & 54 & 500 & 15 & 570 & 3,878 \\
\hline & & & & Rata-R & $\mathrm{a} \mathrm{Ke}$ & . & $\operatorname{lan}(Y$ & & & & & 3,778 \\
\hline
\end{tabular}


$\mathrm{Hal}: 230-244$

Tabel 8. Bobot Nilai dan Perhitungan Rata-Rata Nilai Importance (Y)

\begin{tabular}{|c|c|c|c|c|c|c|c|c|c|c|c|c|}
\hline \multirow{3}{*}{ Variabel } & \multicolumn{10}{|c|}{ Importance $(\mathrm{Y})$} & \multirow{3}{*}{ T otal Skor } & \multirow{3}{*}{$\begin{array}{c}\text { Rata-R ata } \\
\text { (X) }\end{array}$} \\
\hline & \multicolumn{5}{|c|}{ Skala } & \multicolumn{5}{|c|}{ Skor } & & \\
\hline & 1 & 2 & 3 & 4 & 5 & 1 & 2 & 3 & 4 & 5 & & \\
\hline $\mathrm{X} 1.1$ & 0 & 0 & 4 & 122 & 21 & 0 & 0 & 12 & 488 & 105 & 605 & 4,116 \\
\hline $\mathrm{X} 1.2$ & 0 & 0 & 5 & 125 & 17 & 0 & 0 & 15 & 500 & 85 & 600 & 4,082 \\
\hline$X 1.3$ & 0 & 2 & 4 & 129 & 12 & 0 & 4 & 12 & 516 & 60 & 592 & 4,027 \\
\hline $\mathrm{X} 1.4$ & 0 & 0 & 7 & 124 & 16 & 0 & 0 & 21 & 496 & 80 & 597 & 4,061 \\
\hline$X 1.5$ & 0 & 0 & 13 & 120 & 14 & 0 & 0 & 39 & 480 & 70 & 589 & 4,007 \\
\hline X1.6 & 0 & 0 & 7 & 130 & 10 & 0 & 0 & 21 & 520 & 50 & 591 & 4,020 \\
\hline X1.7 & 0 & 2 & 22 & 119 & 4 & 0 & 4 & 66 & 476 & 20 & 566 & 3,850 \\
\hline $\mathrm{X} 1.8$ & 0 & 1 & 22 & 119 & 5 & 0 & 2 & 66 & 476 & 25 & 569 & 3,871 \\
\hline $\begin{array}{l}\mathrm{X} 2.1 \\
\mathrm{n}\end{array}$ & 0 & 2 & 4 & 114 & 27 & 0 & 4 & 12 & 456 & 135 & 607 & $\begin{array}{r}4,129 \\
\quad \mathbf{m}\end{array}$ \\
\hline $\mathrm{X} 2.2$ & 0 & 0 & 6 & 118 & 23 & 0 & 0 & 18 & 472 & 115 & 605 & 4,116 \\
\hline $\mathrm{X} 2.3$ & 0 & 2 & 8 & 108 & 29 & 0 & 4 & 24 & 432 & 145 & 605 & 4,116 \\
\hline X2.4 & 0 & 5 & 3 & 120 & 19 & 0 & 10 & 9 & 480 & 95 & 594 & 4,041 \\
\hline $\mathrm{X} 2.5$ & 1 & 0 & 6 & 124 & 16 & 1 & 0 & 18 & 496 & 80 & 595 & 4,048 \\
\hline $\mathrm{X} 2.6$ & 0 & 1 & 5 & 123 & 18 & 0 & 2 & 15 & 492 & 90 & 599 & 4,075 \\
\hline $\mathrm{X} 2.7$ & 0 & 6 & 11 & 116 & 14 & 0 & 12 & 33 & 464 & 70 & 579 & 3,939 \\
\hline X3.1 & 0 & 2 & 7 & 122 & 16 & 0 & 4 & 21 & 488 & 80 & 593 & 4,034 \\
\hline $\mathrm{X} 3.2$ & 0 & 1 & 7 & 121 & 18 & 0 & 2 & 21 & 484 & 90 & 597 & 4,061 \\
\hline X3.3 & 1 & 0 & 5 & 112 & 29 & 1 & 0 & 15 & 448 & 145 & 609 & 4,143 \\
\hline $\mathrm{X} 3.4$ & 0 & 1 & 14 & 121 & 11 & 0 & 2 & 42 & 484 & 55 & 583 & 3,966 \\
\hline X3.5 & 0 & 3 & 8 & 122 & 14 & 0 & 6 & 24 & 488 & 70 & 588 & 4,000 \\
\hline X3.6 & 0 & 0 & 5 & 122 & 20 & 0 & 0 & 15 & 488 & 100 & 603 & 4,102 \\
\hline X3.7 & 0 & 0 & 6 & 123 & 18 & 0 & 0 & 18 & 492 & 90 & 600 & 4,082 \\
\hline & & & & Rata-R & ata $\mathrm{Ke}$ & selur & han (I & & & & & 4,040 \\
\hline
\end{tabular}


Hal : $230-244$

\section{Tingkat Kesesuaian}

Tabel 9. Tingkat Kesesuaian

\begin{tabular}{|c|c|c|c|c|}
\hline No. & Variabel & $\mathbf{x}$ & $\mathbf{Y}$ & $\begin{array}{l}\text { Persentase } \\
\text { Index } \\
\text { Kepuasan }\end{array}$ \\
\hline $\mathbf{A}$ & Usability Quality & & & \\
\hline 1 & Saya merasa mudah mempelajari cara mengoperasikan web ESS & 581 & 605 & $96,03 \%$ \\
\hline 2 & Saya merasa web ESS user friendly & 575 & 600 & $95,83 \%$ \\
\hline 3 & Saya merasa web ESS mudah untuk dinavigasikan & 563 & 592 & $95,10 \%$ \\
\hline 4 & Saya merasa web ESS mudah digunakan & 571 & 597 & $95,64 \%$ \\
\hline 5 & Web ESS memiliki tampilan yang menarik & 513 & 589 & $87,10 \%$ \\
\hline 6 & Web ESS memiliki design yang sesuai dengan fungsinya & 553 & 591 & $93,57 \%$ \\
\hline 7 & Web ESS menimbulkan rasa kompeten dalam diri saya & 520 & 566 & $91,87 \%$ \\
\hline 8 & Web ESS memberikan pengalaman positif bagi saya & 549 & 569 & $96,49 \%$ \\
\hline B & Information Quality & & & \\
\hline 9 & Web ESS memberikan informasi yang akurat & 551 & 607 & $90,77 \%$ \\
\hline 10 & Web ESS memberikan informasi yang dapat dipercaya & 561 & 605 & $92,73 \%$ \\
\hline 11 & Web ESS memberikan informasi yang terkini & 519 & 605 & $85,79 \%$ \\
\hline 12 & Web ESS memberikan informasi yang relevan & 549 & 594 & $92,42 \%$ \\
\hline 13 & Web ESS memberikan informasi yang mudah dimengerti & 568 & 595 & $95,46 \%$ \\
\hline 14 & $\begin{array}{l}\text { Web ESS memberikan informasi dengan tingkat kedetailan yang } \\
\text { tapat }\end{array}$ & 548 & 599 & $91,49 \%$ \\
\hline 15 & Web ESS memberikan informasi dengan format yang sesuai & 562 & 579 & $97,06 \%$ \\
\hline $\mathbf{C}$ & Interaction Quality & & & \\
\hline 16 & Web ESS memiliki reputasi yang baik & 551 & 593 & $92,92 \%$ \\
\hline 17 & $\begin{array}{l}\text { Web ESS memberikan rasa aman kepada saya dalam } \\
\text { menjalankan setiap transaksi }\end{array}$ & 572 & 597 & $95,81 \%$ \\
\hline 18 & Web ESS menjamin keamanan data pribadi saya & 575 & 609 & $94,42 \%$ \\
\hline 19 & Web ESS menimbulkan suatu perasaan personalisasi & 565 & 583 & $96,91 \%$ \\
\hline 20 & $\begin{array}{l}\text { Web ESS menimbulkan perasaan bahwa saya berada dalam } \\
\text { komunitas atau organisasi }\end{array}$ & 572 & 588 & $97,28 \%$ \\
\hline 21 & $\begin{array}{l}\text { Web ESS memudahkan komunikasi dengan manajemen atau } \\
\text { pihak pengelola SDM }\end{array}$ & 530 & 603 & $87,89 \%$ \\
\hline 22 & $\begin{array}{l}\text { Saya meyakini bahwa informasi yang diberikan Web ESS akan } \\
\text { dilaksanakan }\end{array}$ & 570 & 600 & $95,00 \%$ \\
\hline \multicolumn{4}{|c|}{ Rata - Rata Tingkat Kesesuaian } & $93,53 \%$ \\
\hline
\end{tabular}

Dari data Tabel 9 menunjukkan bahwa nilai rata-rata dari keseluruhan tingkat kesesuaian diperoleh $93,53 \%$ yang berarti bahwa pelayanan pada web ESS masih di bawah $100 \%$ atau di bawah harapan dan pengguna masih merasa tidak puas. 
$\mathrm{Hal}: 230-244$

\section{Analisa GAP}

Tabel 10. Hasil Analisa GAP

\begin{tabular}{|c|c|c|c|c|c|}
\hline No. & Variabel & $\begin{array}{c}\mathbf{X} \\
\left(\mathbf{P}_{\mathrm{i}}\right)\end{array}$ & $\begin{array}{l}Y \\
\left(I_{i}\right)\end{array}$ & $\begin{array}{c}\text { Kepuasan } \\
\left(\mathbf{Q}_{\mathbf{i}}\right)\end{array}$ & Keterangan \\
\hline 1 & Usability Quality & & & & \\
\hline 1.1 & Saya merasa mudah mempelajari cara mengoperasikan web ESS & 3,95 & 4,12 & $-0,16$ & Kurang \\
\hline 1.2 & Saya merasa web ESS user friendly & 3,91 & 4,08 & $-0,17$ & Kurang \\
\hline 1.3 & Saya merasa web ESS mudah untuk dinavigasikan & 3,83 & 4,03 & $-0,20$ & Kurang \\
\hline 1.4 & Saya merasa web ESS mudah digunakan & 3,88 & 4,06 & $-0,18$ & Kurang \\
\hline 1.5 & Web ESS memiliki tampilan yang menarik & 3,49 & 4,01 & $-0,52$ & Kurang \\
\hline 1.6 & Web ESS memiliki design yang sesuai dengan fungsinya & 3,76 & 4,02 & $-0,26$ & Kurang \\
\hline 1.7 & Web ESS menimbulkan rasa kompeten dalam diri saya & 3,54 & 3,85 & $-0,31$ & Kurang \\
\hline 1.8 & Web ESS memberikan pengalaman positif bagi saya & 3,73 & 3,87 & $-0,14$ & Kurang \\
\hline B & Information Quality & & & & \\
\hline 2.1 & Web ESS memberikan informasi yang akurat & 3,75 & 4,13 & $-0,38$ & Kurang \\
\hline 2.2 & Web ESS memberikan informasi yang dapat dipercaya & 3,82 & 4,12 & $-0,30$ & Kurang \\
\hline 2.3 & Web ESS memberikan informasi yang terkini & 3,53 & 4,12 & $-0,59$ & Kurang \\
\hline 2.4 & Web ESS memberikan informasi yang relevan & 3,73 & 4,04 & $-0,31$ & Kurang \\
\hline 2.5 & Web ESS memberikan informasi yang mudah dimengerti & 3,86 & 4,05 & $-0,18$ & Kurang \\
\hline 2.6 & $\begin{array}{l}\text { Web ESS memberikan informasi dengan tingkat kedetailan yang } \\
\text { tapat }\end{array}$ & 3,73 & 4,07 & $-0,35$ & Kurang \\
\hline 2.7 & Web ESS memberikan informasi dengan format yang sesuai & 3,82 & 3,94 & $-0,12$ & Kurang \\
\hline $\mathbf{C}$ & Interaction Quality & & & & \\
\hline 3.1 & Web ESS memiliki reputasi yang baik & 3,75 & 4,03 & $-0,29$ & Kurang \\
\hline 3.2 & $\begin{array}{l}\text { Web ESS memberikan rasa aman kepada saya dalam } \\
\text { menjalankan setiap transaksi }\end{array}$ & 3,89 & 4,06 & $-0,17$ & Kurang \\
\hline 3.3 & Web ESS menjamin keamanan data pribadi saya & 3,91 & 4,14 & $-0,23$ & Kurang \\
\hline 3.4 & Web ESS menimbulkan suatu perasaan personalisasi & 3,84 & 3,97 & $-0,12$ & Kurang \\
\hline 3.5 & $\begin{array}{l}\text { Web ESS menimbulkan perasaan bahwa saya berada dalam } \\
\text { komunitas atau organisasi }\end{array}$ & 3,89 & 4,00 & $-0,11$ & Kurang \\
\hline 3.6 & $\begin{array}{l}\text { Web ESS memudahkan komunikasi dengan manajemen atau } \\
\text { pihak pengelola SDM }\end{array}$ & 3,61 & 4,10 & $-0,50$ & Kurang \\
\hline 3.7 & $\begin{array}{l}\text { Saya meyakini bahwa informasi yang diberikan Web ESS akan } \\
\text { dilaksanakan }\end{array}$ & 3,88 & 4,08 & $-0,20$ & Kurang \\
\hline \multicolumn{2}{|r|}{ Rata - Rata Tingkat Kesesuaian } & 3,78 & 4,04 & $-0,26$ & Kurang \\
\hline
\end{tabular}




\subsection{Analisis Kuadran}

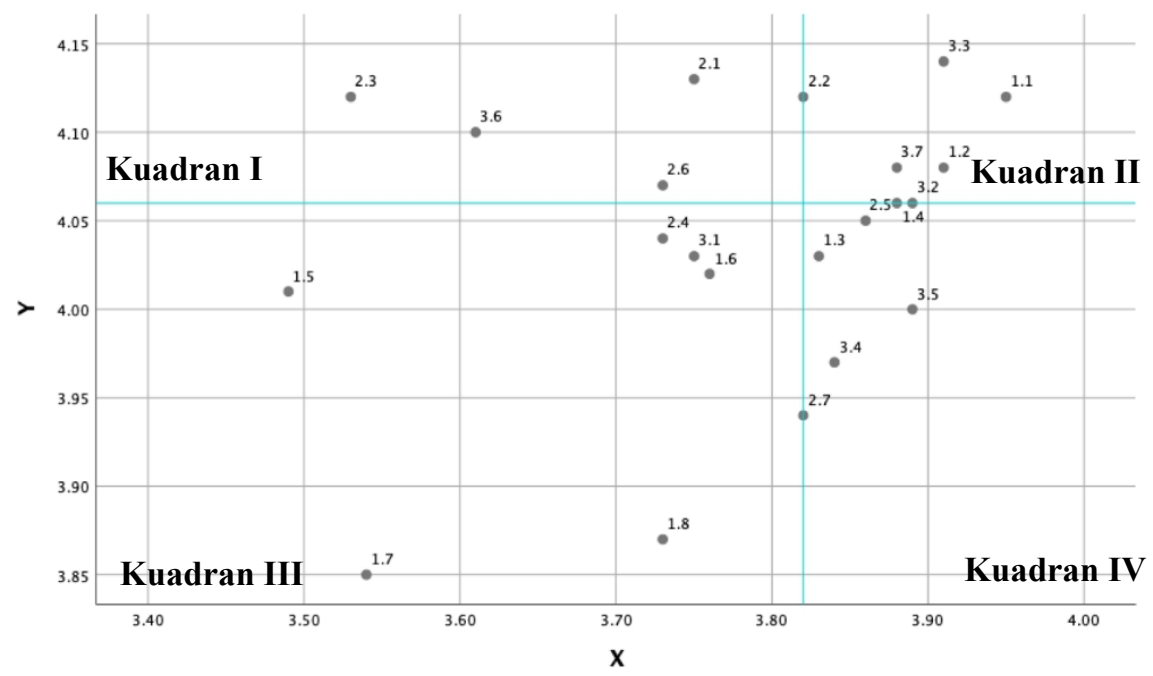

Gambar 3. Analisis Kuadran

Berdasarkan pada Gambar 3, atribut yang harus ditingkatkan terletak pada kuadran I yang terdiri dari pertanyaan nomor 2.1, 2.3, 2.6, 3.6. Sedangkan atribut yang sudah baik terletak pada kuadran II yang terdiri dari pertanyaan nomor 1.1, 1.2, 2.2, 3.3, 3.7. Pada kuadran III menunjukkan atribut yang perlu diperbaiki karena dianggap penting, yaitu pertanyaan nomor $1.5,1.6,1.7,1.8,2.4,3.1$. Kuadran IV menunjukkan atribut yang pelaksanaannya dianggap berlebihan atau yang berada pada pertanyaan nomor 1.3, 1.4, 2.5, 2.7, 3.4, dan 3.5.

\section{SIMPULAN}

Hasil dari penelitian dengan menggunakan metode WebQual 4.0 dan IPA menyimpulkan bahwa:

1. Sebesar 71 responden tidak puas terhadap Performance web ESS, 34 responden merasa sangat puas terhadap Performance web ESS, dan 42 responden merasa puas dengan Performance web ESS.

2. Rata-rata dari keseluruhan tingkat kesesuaian diperoleh 93,53\% yang berarti bahwa Performance pada web ESS masih di bawah Importance dan pengguna masih merasa tidak puas.

3. Dengan hasil Analisa $G A P$ sebesar $-0,262<0$ maka dari itu bisa dikatakan kualitas kinerja masih kurang dan belum bisa memenuhi kepentingan pengguna.

4. Hasil yang didapatkan setelah menganalisis dengan analisis kuadran maka:

a. Kuadran I sebagai prioritas dalam perbaikan pelayanan web karena memiliki kepentingan yang tinggi sedangkan kinerjanya rendah, yaitu mengenai penyajian informasi yang terkini, informasi yang akurat, informasi yang detail, dan kemudahan berkomunikasi dengan pengelola.

b. Kuadran II sebagai kualitas yang harus tetap dipertahankan dikarenakan kepentingan dan kinerjanya sama-sama tinggi, yaitu mengenai cara mempelajari kemudahan pengoperasian, kemudahan dalam pemahaman terhadap interaksi, informasi yang diberikan dapat dipercaya, keamanan data pribadi, informasi yang diberikan akan dilaksanakan. 
c. Kuadran III dikatakan kuadran ini memiliki tingkat kinerja dan kepentingannya sama-sama rendah maka bisa dikatakan kinerja dari pada web tidak begitu mempengaruhi kepentingan, yaitu tampilan yang menarik, design web, menimbulkan rasa kompetensi diri, pengalaman positif, informasi yang relevan, reputasi yang baik.

d. Kuadran IV dikatakan memiliki kualitas terhadap web terlalu berlebihan yang artinya kinerja dari pada web sangat tinggi akan tetapi kepentingannya sangat rendah, pada web ini kemudahan dinavigasikan, mudah digunakan, informasi yang diberikan mudah dimengerti, informasi dengan format yang sesuai, menimbulkan perasaan personal, menimbulkan perasaan bahwa saya berada dalam komunitas atau organisasi dianggap berlebihan.

\section{UCAPAN TERIMAKASIH}

Terima kasih kepada STMIK Nusa Mandiri dan Universitas Bina Sarana Informatika tempat dimana penulis mengabdi dan mendapat dukungan untuk terus berkarya dalam penelitian. Semoga penelitian ini dapat bermanfaat bagi semuanya.

\section{DAFTAR PUSTAKA}

[1] A. Meyliana, "Pengukuran Kualitas Situs Jual Beli Online Menggunakan Metode WebQual," Indones. J. Softw. Eng., vol. 4, no. 1, pp. 14-20, 2018, doi: 10.31294/ijse.v4i1.6232.

[2] M. Kharisma and S. Anggraeni, "Pengaruh Kualitas Layanan Bjb Net Terhadap Kepuasan Nasabah Bank Bjb Rasuna Said Menggunakan Metode Webqual 4.0," J. TECHNO Nusa Mandiri, vol. 15, no. 1, pp. 13-18, 2018, [Online]. Available: http://ejournal.nusamandiri.ac.id/ejurnal/index.php/techno/article/viewFile/808/pdf.

[3] Y. T. Karina and W. Andhyka, "Evaluasi Kualitas Layanan Website Simanta Pkn Universitas Muhammadiyah Malang Dengan,” vol. 2, pp. 11-16, 2018.

[4] L. Nasution, I. Aknuranda, and A. Rachmadi, "Evaluasi Situs Web Pemerintah Menggunakan Metode Webqual Dan Importance-Performance Analysis ( IPA ) ( Studi Kasus: Situs Kecamatan Lowokwaru-Malang )," J. Pengemb. Teknol. Inf. dan Ilmu Komput. Univ. Brawijaya, vol. 2, no. 11, pp. 4377-4384, 2018.

[5] M. Feb and R. Setyorini, "PENGUKURAN KEPUASAAN PENGGUNA WEBSITE VIU . COM DENGAN MENGGUNAKAN PENDEKATAN ANALYSIS Digital Video Disc atau sering disebut," Din. Ekon. J. Ekon. dan Bisnis, vol. 12, no. 1, pp. 33-50, 2019, [Online]. Available: https://stienasypb.ac.id/jurnal/index.php/jdeb/article/view/172.

[6] R. Kemala, D. Siregar, and R. A. Fitriawan, “Analisis Kualitas Website Ruangguru . Com Menggunakan Webqual 4 . 0 Dan Ipa (Importance Performance Analysis ) Ruangguru . Com Website Quality Analysis Using Webqual 4 . 0 and Ipa (Importance Performance Analysis )," vol. 5, no. 1, pp. 1201-1208, 2018.

[7] A. P. Kurniawan, "Pengukuran Kualitas Website Universitas Telkom Menggunakan Metode WebQual 4.0," Inst. Teknol. Telkom Purwokerto, pp. 1-5, 2018, [Online]. Available: http://conferences.ittelkom-pwt.ac.id/index.php/centive/article/view/1.

[8] P. Metode, W. Terhadap, A. Manik, I. Salamah, and E. Susanti, "Pengguna Website Politeknik Negeri Sriwijaya the Impact of Webqual 4 . 0 Method Towards User," J. 
Elektro dan Telekomun. Terap., pp. 477-484, 2017.

[9] ilham U. Zamani, D. Sunarto, and andrian I. Mastan, "Analisis Pengaruh Kualitas Website PT Badak Issn 2338-137X," vol. 5, no. 11, pp. 1-8, 2016, [Online]. Available: https://jurnal.dinamika.ac.id/index.php/jsika/article/view/1387.

[10] D. Dafid, "Penggunaan Metode IPA dan WebQual untuk Mengukur Kualitas Sistem Informasi Akademik," J. Ilm. Inform. Glob., vol. 9, no. 2, pp. 71-76, 2018, doi: 10.36982/jig.v9i2.540.

[11] V. Herlina, Panduan Praktis Mengolah Data Kuesioner Menggunakan SPSS. Jakarta: Elex Media Komputindo, 2019.

[12] I. P. A. A. Payadnya and I. G. A. N. T. Jayantika, Panduan Penelitian Eksperimen Beserta Analisis Statistik Dengan SPSS. Yogyakarta: CV. Budi Utama, 2018.

[13] I. Jaya, Penerapan Statistik Untuk Penelitian Pendidikan. Jakarta: Prenada Media, 2019.

[14] R. A. Purnomo, Analisa Statistik Ekonomi dan Bisnis dengan SPSS. Ponorogo: CV. Wade Group, 2016. 